\title{
Delineation of Ground Water Potential Zones Using GIS and Remote Sensing Techniques in the Case of Korahe zone, Somali regional state, Ethiopia
}

\author{
AbdoWudad*1 Dereje Biru $^{2}$ Ashenafi Darcho $^{3}$ Endris Mohammed $^{4}$ and Fekadie Bazie $^{5}$ \\ ${ }^{1,3,4,5}$ Kebri Dehar University, Department of Geography and Environmental Studies, P.O. Box 250, Kebridehar, Ethiopia \\ ${ }^{2}$ Bonga University, Department of Geography and Environmental Studies, P.O. Box 334, Bonga, Ethiopia
}

DOI: 10.29322/IJSRP.11.08.2021.p11653

http://dx.doi.org/10.29322/IJSRP.11.08.2021.p11653

\begin{abstract}
The integration of GIS and remote sensing was applied to delineate ground water potential zone by interpreting nine thematic layers. The parameters like drainage density, elevation, geology, geomorphology, land use and land cover, lineaments, rainfall pattern, slope gradient and soil texturewere used for identification of ground water potential within the study area. The selected parameters are prepared and classified in the GIS environment, then the analytical hierarchy process is used to assign weights to each parameter and its class, and finally the results are found in the weighted overlay analysis that is common in ArcGIS. The result of the study reveals that, about 169631.71ha $(4.89 \%)$ of the study area having very high,334818.58ha $(9.65 \%)$ having high, 587658.05ha $(16.93 \%)$ having moderate, 1194164.18 ha $(34.41 \%)$ having low and 1184005.67 ha $(34.12 \%)$ having very low potential of ground water. The integration of GIS and Remote sensing technique in ground water analysis from various thematic maps proves to be very important to map the groundwater occurrence and movement for recharge potential mapping and management plan on a scientific basis in the study area.
\end{abstract}

Keywords: GIS, Remote sensing Analytical hierarchical process, Weighted Overlay, groundwater zone

\section{Introduction}

According to National Groundwater Association (NGWA) Report, GW (Ground water) is the most widely used source of fresh water and extracted as raw materials with withdrawals rate currently in the estimate range of $982 \mathrm{~km} 3 / \mathrm{year}$ in the world. About $60 \%$ of groundwater withdrawals worldwide is used for agriculture, which is globally about $38 \%$ of irrigated land is equipped for irrigation with groundwater and about of $25 \%$ to $40 \%$ was used for domestic and the rest is used for industry (Siebert et al., 2010).

In Ethiopia, the annual water resources potential is estimated to be $122 \mathrm{BCM}$ with $40 \mathrm{BCM}$ of groundwater potential and 28-36 BCM of annual groundwater recharge (Puertas, 2015). According to MoWR (2012) report, in Ethiopia, Groundwater potential is shaped by complex geological formation and the diversity of topography, climate, and soil. According to Berhanu et al. (2014), the difficulty in obtaining productive aquifers is an odd feature in Ethiopia, because it's characterized by the wide heterogeneity of geology, topography, and environmental conditions. Actually, the geology of the country provides usable $\mathrm{GW}$ and provides good transmission of rainfall to recharge aquifers, and produce springs and feeds perennial rivers. The geological formations/water bearing rock with sufficient saturated permeable materials are transmitted and yield water in significant quantity towards point of discharge (Bereket, 2017). In many parts of the country, GW is the major source of water supply for meeting domestic need, industrial, irrigation and other developmental initiatives, due to its longer resident time in the ground, low level of contamination, wide distribution, and availability (Sewnet et al., 2016). 
The occurrence, distribution and movement of groundwater resource in any place is not a matter of chance, but the interaction of different factors such as climate (rainfall), geomorphological (land feature, land use/cover), physiographical (topography), hydrological (drainage density, water bodies, etc.), geological factors, lineament density and soil (Murasingh and Jha, 2013). However, the extent to which the factors affect the ground water may differ from place and time. Considering this factor has significant potential to evaluate the groundwater resource and improve success in selecting the favorable sites for boreholes and wells (Badamasiet al., 2016).

Around the world, different methods have been used in delineating GWPZs such as integration of remote sensing and GIS with resistivity data (Selvarani et al.,2016), influence factor (IF) (Selvam et al.,2015; Magesh et al.,2012 and , Nasir et al.,2018), statistical methods (Machiwal etal.,2011; Falah et al.,2017), groundwater modeling (Sashikkumar et al.,2017), and analytical hierarchy process (AHP) (Das et al.,2018; Dar et al.,2020, Saranya and Saravanan,2020). These methods have been proven as reliable and effective, and have been used by many researchers. Among those, AHP is advisable in cases of segregating multiple substitutes to a set of pairwise comparisons followed by the incorporation of the result. As propounded by (Saaty, 1980), AHP is also recommended when there is a lack of sufficient valid data for analysis (Saaty, 2014 and Souissi, 2018). AHP approach has been broadly applied in many fields of natural resources management, regional planning, and environmental impact assessment (Kaliraj, 2014 and,Rahaman, 2015). In the present study, AHP is integrated with RS-GIS techniques for the identification of GWPZs in the Koarhe zone. Similar to (Arshad et al., 2020; Kumar, et al., 2020, Bisson and Lehr,2014; Naghibiet al., 2015 and Mallick et al.,2019), weights are allocated to the different parameters and their feature classes based on extensive literature reviews and expert knowledge using the AHP method. The integration of RS-GIS with AHP results in the conversion of data to obtain valuable information for managers and policymakers (Malczewski et al., 2006). Therefore the main objective of this study is to map and delineate groundwater potential zones of the Korahe zone through the integration of RS-GIS with AHP. For this purpose, we utilized nine thematic layers (i.e., geology, geomorphology (landforms), slope, elevation, soil texture, lineament density, drainage density and rainfall, land use/land cover) in the analysis. This study would be a useful for groundwater resources planners and managers when constructing sustainable groundwater plans in this region.

\section{Study area}

Korahey is one of the 11 zones of the Somali region of Ethiopia. It is bordered by the Gode zone to the southwest, Fiq to the northwest, Degahapur to the north, Werder to the east, and the Republic of Somalia to the southeast. The largest city in Korahe is Kebri Dahar. Astronomically, Korahe zone is found between 6 ${ }^{\circ} 28^{\prime}-7 \circ 68^{\prime}-\mathrm{N}$ Latitude to $43^{\circ} 53^{\prime}-45^{\circ} \mathrm{oo}^{\prime}$ E longitude, respectively (Figure2.1). Based on the 2007 Census conducted by the Central Statistical Agency of Ethiopia (CSA), the Zone has a total population of 312,713, of whom 177,919 are men and 134,794 women. The largest ethnic group reported in Korahey was the Somali (99.22 percent) in which their livelihood was predominantly based on livestock production. Korahey Zone is well known for its endowment with huge potential of natural resources, the natural gas field of Calub lies in this zone, making petrochemical extraction potential area in the country (Abdulahi et al 2020). Moreover, the community is known for preserving and maintaining a wide-variety of cultural values and historical heritages, which are recognized to be its typical identities, and which need to be further promoted and strengthened. The zone is characterized by topography ofpredominantly lowland plain with an average altitude of $493 \mathrm{~m}$ above sea level with a few foothills of higher altitude. According to national meteorology agency of Ethiopia, the climate of Korahe zone is characterized as tropical semiarid in which temperature ranges from 23 to $36{ }^{\circ} \mathrm{C}$. The area has bimodal rainfall pattern with two main rainy seasons in which the first is ' $\mathrm{Gu}$ ' that occurs from mid-April to the end of June and second rainy season known as 'Deyr' occurs from early October to late December (Wudad et al, 2021). 


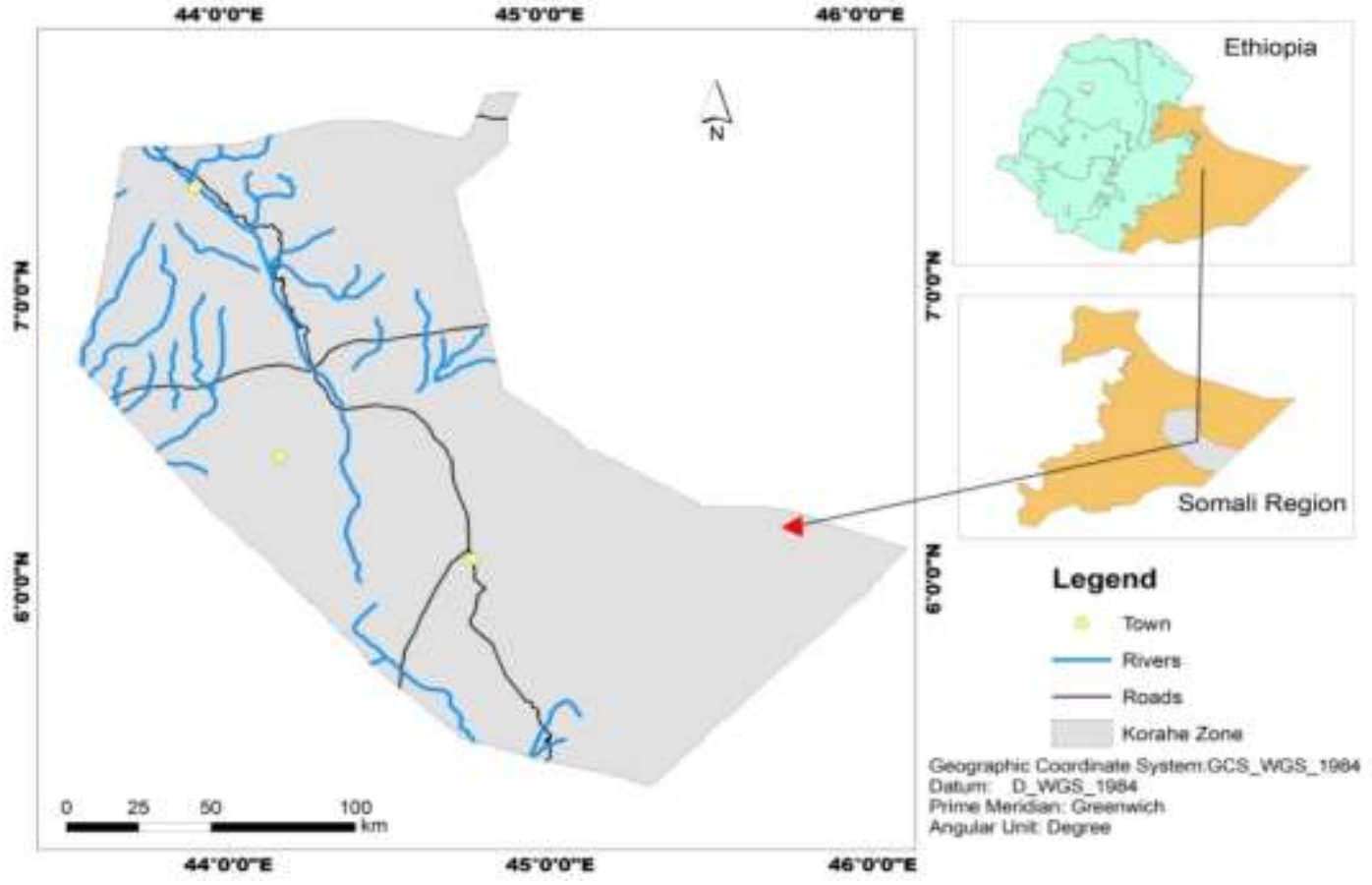

Figure 2.1.Location map of Korahe zone.

\section{Methodology}

To delineate ground water zone of the study area we developed a thematic layers from different factors such as geology, slope, lineaments density, soil, elevation, drainage density and land cover using GIS-MCDA techniques. The data layer for each of these factors was generated and classified using a series of satellite data, existing maps, and data from related governmental organizations, all these thematic layers were integrated using GIS and MCDA methods (Table3.1).

Soil data was in shape file form representing polygons of different soils texture. They were imported into ArcGIS 10.8 platform where they were explored and displayed in map format. It was ensured also that the data adequately covered the area of study. The climate data obtained from national meteorology agency were in Excel file format. They were scrutinized on excel spreadsheet to ensure that all the values representing both temperature and rainfall were free from obvious errors and mistakes. In the MS Excel file containing the climate data, spatial data in terms of latitudes and longitudes of the locations of weather stations were entered into corresponding climate data. In the climate data, averaging was done starting from the year 1980 up to the year 2018 in the excel spreadsheet. The results were exported to the ArcGIS 10.8 software for further manipulation. To generate raster image from the data we used a geostatistical method of interpolation called ordinary kriging to interpolate point data into a continuous surface. The resultant image was then clipped to the study area by use of the Korahe zone boundary. Elevation map was generated from SRTM 30 meter resolution Digital Elevation Model (DEM), and then clipped to the study area using the existing Korahe zone administrative boundary. From the elevation data, slope and drainage density was derived by using Spatial Analyst Tool in ArcGIS environment.

Sentinel-2A image were downloaded from USGS and imported into ERDAS IMAGINE 2015 software then mosaicked into a continuous image, projected into UTM zone 37N and WGS84 datum, and clipped to the study area extend. Radiometric correction was done for image correction to reduce atmospheric effects. The final task involved carrying out supervised classification comprising of six classes namely: Trees cover areas, Shrubs cover areas, Grassland, Cropland, Vegetation aquatic or regularly flooded, Lichen Mosses / Sparse vegetation, bare areas, built up areas and Open water. Landsat 8 image (OLI) of the study area was downloaded from USGS to prepared lineament map using the line module of PCI Geomatica (Hashim et, al 2013).

After processing, all data sets were imported into the geodatabase in feature class and raster formats. By using data stored in geodatabase, standardization of the various criteria into a common standard was possible. To perform weighted overlay, the criteria which is in different units need to be in same units and hence needed to be standardized. 
Standardization makes the measurement units uniform, and the scores lose their dimension along with their measurement unit (Effat and Hassan, 2013). Therefore in this study all criteria maps have been reclassified into five classes (very low, low, moderate, high, and very high) values ranging from 1 to 5, where 1 represents very low and 5 represents veryhigh.Their levels of groundwater availability were decided supported data collected from the varied scientific literature (Table 3.2).For each criterion; weights were derived in IDRISI software using AHP methods. Supported the relative importance, values starting from 1 to 9 were assigned to every factor to construct AHP matrix as described by Saaty (1980). Same as size 1 means equally important, 9 means extremely important. The matrix is created, to calculate priority weights from the pairwise comparison matrix and eigenvector values as shown within the following formula.

eigen vector $\left.=\mathrm{Aji}=\frac{\sum_{i=1}^{n}\left(\frac{w 1}{w 1} * \frac{w 1}{w 2} * \ldots * \frac{w 1}{w n}\right)^{1 / n}}{\Sigma\left[\sum_{i=1}^{n}\left(\frac{w 1}{w 1} * \frac{w 1}{w 2} * \ldots * * \frac{w 1}{w n}\right)\right.}\right)^{1 / n}(1)$

Where $\mathrm{w} 1$ is the sum of row for pairwise comparison and $\mathrm{n}$ is the size of matrix

The consistency ratio (CR) was calculated to verify the consistency of comparison as:

$\mathrm{CI}=\frac{(\lambda \max -n)}{n-1}$

Where CI is the consistency index, $\mathrm{n}$ is the number of elements being compared in the matrix,max is the largest or principal eigenvalue of the matrix.

$\mathrm{CR}=\frac{C I}{R I}$

Where $\mathrm{CR}$ is the consistency ratio, $\mathrm{CI}$ is the consistency index, $\mathrm{RI}$ is the random index

\begin{tabular}{lcccccccccc}
\hline Matrix size & 1 & 2 & 3 & 4 & 5 & 6 & 7 & 8 & 9 & 10 \\
\hline $\begin{array}{l}\text { Random consistency } \\
\text { index(RI) }\end{array}$ & 0 & 0 & 0.58 & 0.9 & 1.12 & 1.24 & 1 & 1.41 & 1.45 & 1.49 \\
\hline
\end{tabular}

Random Index (Staay,1980)

If the $\mathrm{CR} \leq 0.10$, it means the pairwise comparison matrix has a suitable consistency. Otherwise, If $\mathrm{CR} \geq 0.10$ it implies that pairwise consistency has inadequate consistency (Bozdag et al., 2016). Following the standards weight, the standardized criteria were aggregated by using weighted overlay, and suitability maps were then produced according to:

$\mathrm{s}=\sum_{i=0}^{n}(W i X i)(4)$

Where $\mathrm{S}$ is the suitability, Wi is the weight of factor $\mathrm{i}$, and $\mathrm{Xi}$ is the criterion score of factor $\mathrm{i}$.

Table 3.1.Summary of data types and their sources.

\begin{tabular}{|c|c|c|c|c|}
\hline $\begin{array}{l}\text { Data } \\
\text { Types }\end{array}$ & Data & Source of data & $\begin{array}{l}\text { Scale/Resolution } \\
\text { /Format }\end{array}$ & Functions \\
\hline \multirow[t]{2}{*}{ 胥 } & $\begin{array}{l}\text { Landsat } 8 \\
\text { operational } \\
\text { land imager } \\
\text { (OLI) satellite } \\
\text { image }\end{array}$ & $\begin{array}{l}\text { United States } \\
\text { Geological } \\
\text { Society }\end{array}$ & $30 * 30 \mathrm{~m}$ & $\begin{array}{l}\text { Used to generate } \\
\text { lineament density } \\
\text { map of the study } \\
\text { area }\end{array}$ \\
\hline & $\begin{array}{l}\text { Sentinel-2A } \\
\text { image }\end{array}$ & $\begin{array}{l}\text { Ethiopian } \\
\text { geospatial } \\
\text { information }\end{array}$ & $10 * 10 \mathrm{~m}$ & $\begin{array}{l}\text { Used to generate } \\
\text { Land use Land } \\
\text { cover map of the }\end{array}$ \\
\hline
\end{tabular}

This publication is licensed under Creative Commons Attribution CC BY. 


\begin{tabular}{|c|c|c|c|c|}
\hline & \multicolumn{3}{|c|}{ agency } & \multirow{2}{*}{$\begin{array}{l}\text { study area } \\
\text { Used to derive } \\
\text { slope, elevation , } \\
\text { Geomorphology } \\
\text { and drainage } \\
\text { density map }\end{array}$} \\
\hline & $\begin{array}{l}\text { A Digital } \\
\text { Elevation } \\
\text { Model (Dem) }\end{array}$ & $\begin{array}{l}\text { Shuttle Radar } \\
\text { Topography } \\
\text { Mission }\end{array}$ & $30 * 30 \mathrm{~m}$ & \\
\hline & $\begin{array}{l}\text { The rainfall } \\
\text { data of } 36 \\
\text { years(1980- } \\
\text { 2016) }\end{array}$ & $\begin{array}{l}\text { National } \\
\text { Meteorology } \\
\text { Agency }\end{array}$ & Excel Format & $\begin{array}{l}\text { Used to generate } \\
\text { Rainfall map of the } \\
\text { study area }\end{array}$ \\
\hline & $\begin{array}{l}\text { Geological } \\
\text { data }\end{array}$ & $\begin{array}{l}\text { Ethiopian } \\
\text { geological } \\
\text { survey } \\
\end{array}$ & $\begin{array}{l}\text { at a scale of 1: } \\
250,000\end{array}$ & $\begin{array}{l}\text { Used to generate } \\
\text { Geological map of } \\
\text { the study area }\end{array}$ \\
\hline 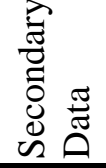 & Soil Texture & $\begin{array}{l}\text { Food and } \\
\text { agricultural } \\
\text { organization }\end{array}$ & Shape File & $\begin{array}{l}\text { Used to develop } \\
\text { Soil map of the } \\
\text { study area }\end{array}$ \\
\hline
\end{tabular}

Table 3.2.Criteria considered for Groundwater potential zone selection.

\begin{tabular}{|c|c|c|c|c|c|}
\hline Criteria & $\stackrel{\mathscr{\Xi}}{\circ}$ & $\frac{n}{\tilde{0}}$ & 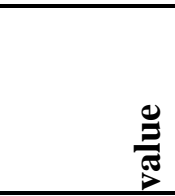 & 总离 & 递 \\
\hline \multirow{5}{*}{ Geomorphology } & \multirow{5}{*}{ Class } & Hills, Badland & 1 & Very low & $\begin{array}{l}\text { (Allafta et al.,2021;Nagaraju, } \\
\text { 2016;Mahalingam\& Vinay, } \\
\text { 2015;Arumaikkani et al., 2017) }\end{array}$ \\
\hline & & Structural landform & 2 & Low & (Lammesa, 2017) \\
\hline & & $\begin{array}{l}\text { Pediment/Pedi plain,Foot } \\
\text { slopes }\end{array}$ & 3 & Moderate & $\begin{array}{l}\text { (Ghodratabadi\&Feizi, } \\
\text { 2015;Nagaraju, 2016) }\end{array}$ \\
\hline & & $\begin{array}{l}\text { Valley/flat,Plain surfaces } \\
\text { between } 500 \text { and } 1000 \mathrm{~m}\end{array}$ & 4 & High & $\begin{array}{l}\text { (Jeyapprabha et al.,2014 ;Nagaraju, } \\
\text { 2016;Ghodratabadi \&Feizi, 2015) }\end{array}$ \\
\hline & & $\begin{array}{l}\text { Mountain with an } \\
\text { altitude of } 500 \text { meters. }\end{array}$ & 5 & $\begin{array}{l}\text { Very } \\
\text { High }\end{array}$ & (Ghodratabadi\&Feizi, 2015) \\
\hline \multirow[t]{5}{*}{ Geology } & \multirow[t]{5}{*}{ Class } & Pyroclastic & 1 & Very low & (Oboko et al., 2021) \\
\hline & & $\begin{array}{l}\text { Plutonic } \\
\text { Igneous, Volcanic } \\
\text { Igneous }\end{array}$ & 2 & Low & (Allafta et al.,2021) \\
\hline & & Limestone & 3 & Modearte & (Aryanto\&Hardiman, 2018). \\
\hline & & Sandstone/conglomerate & 4 & High & (Barik et al., (2017). \\
\hline & & $\begin{array}{l}\text { Unconsolidated } \\
\text { Sediments }\end{array}$ & 5 & Very high & (Allafta et al.,2021) \\
\hline \multirow[t]{4}{*}{ LULC } & \multirow[t]{4}{*}{ Class } & Bare-land and Settlement & 1 & Very low & \multirow{4}{*}{ (Das, 2017) } \\
\hline & & Shrub land & 2 & Low & \\
\hline & & Farmland and Grassland & 3 & Moderate & \\
\hline & & Forest & 4 & High & \\
\hline
\end{tabular}




\begin{tabular}{|c|c|c|c|c|c|}
\hline & & & & & \\
\hline & & Waterbody and Wetland & 5 & Very high & \\
\hline \multirow{5}{*}{ Soil Texture } & \multirow{5}{*}{ Class } & Clay & 1 & Very low & \multirow[b]{2}{*}{$\begin{array}{l}\text { (Tripathiet al,2017; Ibrahim-Bathis } \\
\text { and Ahmed, 2016)FAO, 1998) }\end{array}$} \\
\hline & & Clay loam & 2 & Low & \\
\hline & & Sandy clay loam,Loam & 3 & \multicolumn{2}{|l|}{ Moderate } \\
\hline & & Sandy loam & 4 & High & \\
\hline & & Sandy and wetland & 5 & Very high & \\
\hline Drainage density & $\mathrm{Km} / \mathrm{km} 2$ & \multicolumn{3}{|c|}{$\begin{array}{l}\text { Areas with low drainagedensitywas } \\
\text { characterized as high groundwater }\end{array}$} & $\begin{array}{l}\text { (Ibrahim-bathis and ahmed, 2016; } \\
\text {; Rahmati et al., 2015; } \\
\text { Yildiz, 2004; rajaveniet al., 2017; } \\
\text { Andualem and demeke, 2019; } \\
\text { Tolche,2020) }\end{array}$ \\
\hline $\begin{array}{l}\text { Lineament } \\
\text { density }\end{array}$ & $\mathrm{Km} / \mathrm{km} 2$ & \multicolumn{3}{|c|}{$\begin{array}{l}\text { Areas having high lineament density } \\
\text { Was characterized as } \\
\text { High groundwater recharge areas }\end{array}$} & $\begin{array}{l}\text { (Yeh et al., 2016; } \\
\text { Naghibi et al., 2017; } \\
\text { Rajaveni et al.; 2017; }\end{array}$ \\
\hline Rainfall & $\mathrm{Mm}$ & \multicolumn{3}{|c|}{$\begin{array}{l}\text { The ground water is high if the rainfall is high and } \\
\text { it is low if rainfall } \\
\text { Is low }\end{array}$} & (Mahalingam\&vinay, 2015) \\
\hline Elevation & $\mathrm{M}$ & \multicolumn{3}{|c|}{$\begin{array}{l}\text { The, lower the elevation, the higher the } \\
\text { ground water potential }\end{array}$} & (Gedebo,2005) \\
\hline Slope & $\%$ & \multicolumn{3}{|c|}{$\begin{array}{l}\text { the flat slopes decrease the runoff and increase the } \\
\text { infiltration of surface water intoground which } \\
\text { can increase the ground water recharge }\end{array}$} & $\begin{array}{l}\text { Tolche, 2020;;mahalingam\&vinay, } \\
\text { 2015; Andualem and Demeke, 2019) }\end{array}$ \\
\hline
\end{tabular}




\section{Result and Discussions}

\subsection{Drainage density}

The drainage density of the study area was prepared from the digital elevation model ( $30 \mathrm{~m}$ x $30 \mathrm{~m}$ resolution) in ArcGIS 10.5 platform. The result shows that about $26.26 \%$ of the total area has very high ground water availability followed by $24.4 \%$ which have moderate ground water availability. The remaining $22.43 \%, 18.09 \%$ and $8.76 \%$ of the total area has low and very low water availability respectively (Table 4.1 and Figure 4.1). The drainage density has an inverse relation with the permeability of aquifers and plays a significant role within the runoff distribution and level of infiltration (Rahmati et al., 2015; Yildiz, 2004; Rajaveni et al., 2017).

Table 4.1.Drainage density class with respective Ground water availability.

\begin{tabular}{llrrr}
\hline $\begin{array}{l}\text { Draiange density } \\
\text { class }\left(\mathrm{km} / \mathrm{km}^{2}\right)\end{array}$ & $\begin{array}{l}\text { Ground water } \\
\text { availability }\end{array}$ & Value & & Area (\%) \\
\hline $0.16-0.29$ & very low & 1 & 307248.11 & 8.76 \\
$0.11-0.16$ & Low & 2 & 634745.25 & 18.09 \\
$0.07-0.11$ & Moderate & 3 & 858142.00 & 24.46 \\
$0.03-0.07$ & High & 4 & 787014.31 & 22.43 \\
$0-0.03$ & very High & 5 & 921479.84 & 26.26 \\
\hline
\end{tabular}

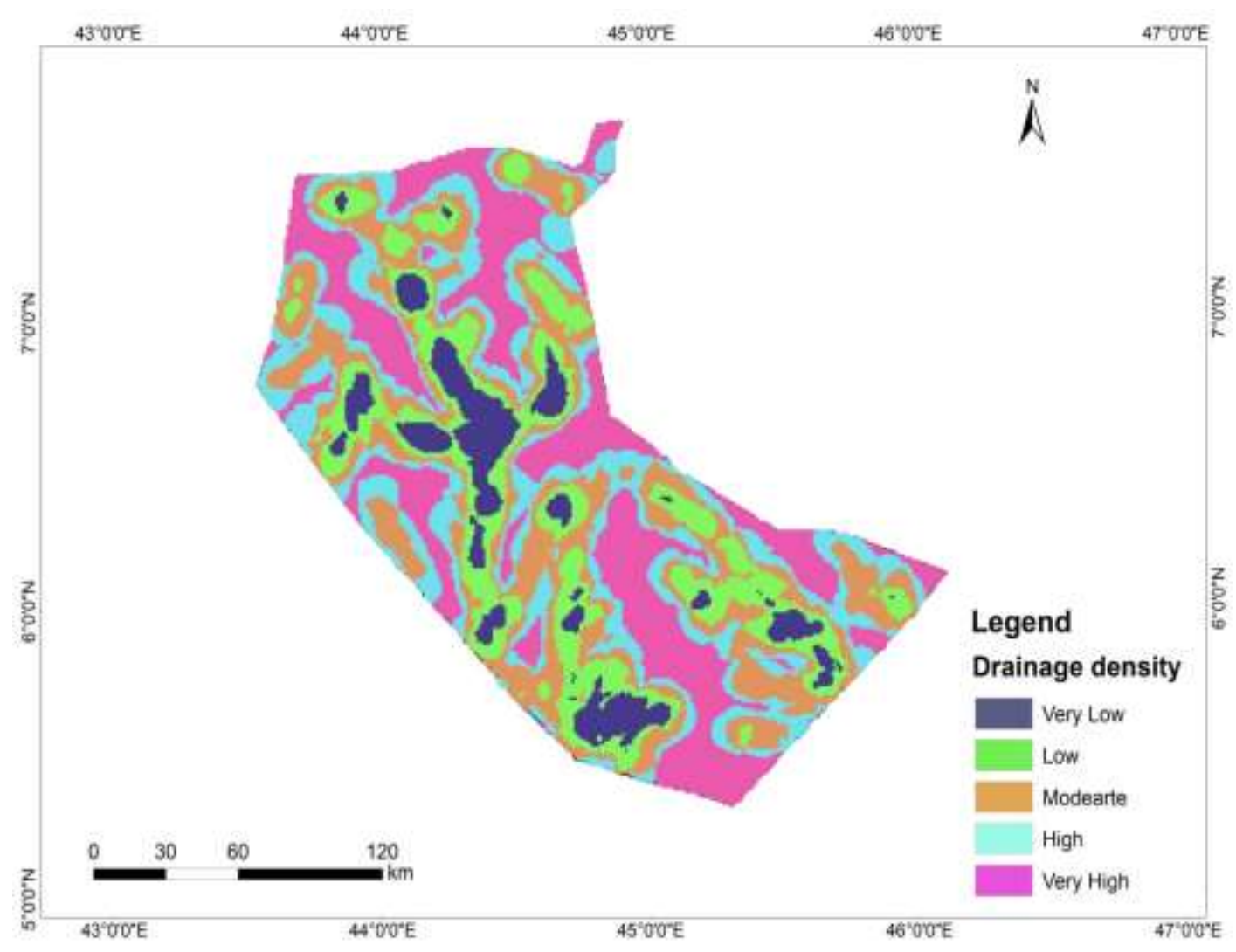

Figure 4.1 Reclassified Drainage density map.

\subsection{Lineament density}

Various Studies reveals that lineament density has a direct relation with ground water availability. For example Yehet al., (2016); Naghibi et al., (2017);Tolche, (2020) stated that areas with high lineament density are good for groundwater potential zones. In this study the result of lineament density of the study area which was prepared from Landsat 8 (OLI) satellite image reveals that $74.24 \%$ of the study area has very low ground water. $8.32 \%$ low, $8.20 \%$ moderate, $5.62 \%$ high 
and $3.62 \%$ very high respectively. From this we can infer that the ground water availability of the study area is very low with respect to lineament density.

Table 4.2.Lineament density class with respective Ground water availability.

\begin{tabular}{lllll}
\hline $\begin{array}{l}\text { Lineament } \\
\text { class }\left(\mathrm{km} / \mathrm{km}^{2}\right)\end{array}$ & $\begin{array}{l}\text { Ground water } \\
\text { availability }\end{array}$ & value & Area(Ha) & Area $(\%)$ \\
\hline $0-0.02$ & very low & 1 & 2606696.78 & 74.24 \\
$0.02-0.05$ & Low & 2 & 292225.61 & 8.32 \\
$0.05-0.09$ & Moderate & 3 & 287834.56 & 8.20 \\
$0.09-0.14$ & High & 4 & 197454.76 & 5.62 \\
$0.14-0.23$ & very High & 5 & 127072.95 & 3.62 \\
& & & & \\
\hline
\end{tabular}

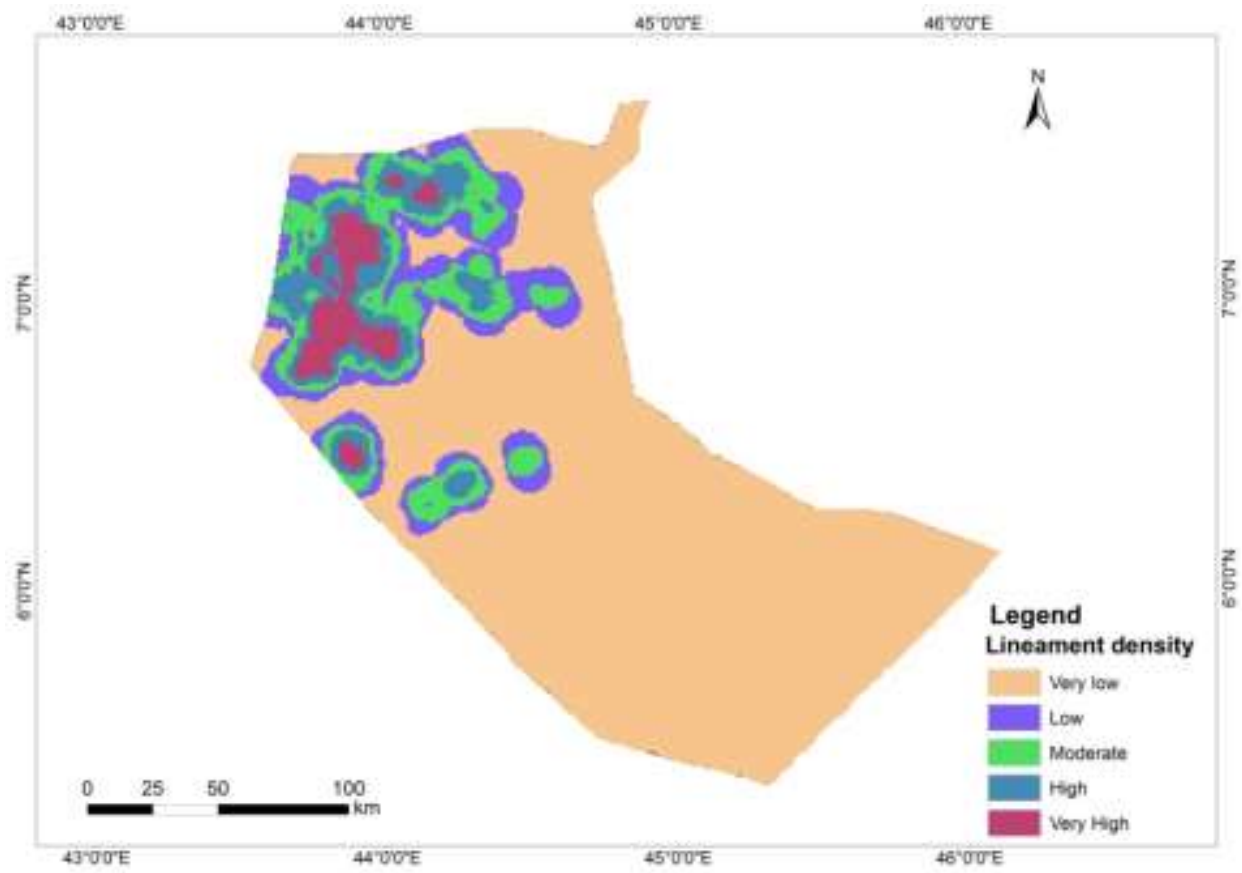

Figure 4.2 Reclassified Lineament density map.

\subsection{Rainfall}

In relation to rainfall, the ground water potential zone is again very low due to minimum amount of the rainfall availability in the study area. The possibility of ground water availability is high if the rainfall is high and it is low if rainfall is low (Mahalingam and Vinay, 2015). This study has considered the annual mean rainfall from the year 1980 to 2018 and the result indicates about $50 \%$ of the total area is characterized by very low and low ground water availability. $18.55,17.91 \%$ and $13.59 \%$ is identified as the areas having moderate, high and very high ground water potential respectively.

Table 4.3.Rainfall class with respective Ground water availability.

\begin{tabular}{|c|c|c|c|c|}
\hline $\begin{array}{l}\text { Rainfall } \\
\text { class(mm) }\end{array}$ & $\begin{array}{l}\text { Ground } \\
\text { availability }\end{array}$ & water & Area(Ha) & Area $(\%)$ \\
\hline $236-258$ & very low & 1 & 908670.83 & 25.87 \\
\hline $254-284$ & Low & 2 & 845246.55 & 24.07 \\
\hline 284-312 & Moderate & 3 & 651521.54 & 18.55 \\
\hline
\end{tabular}




\begin{tabular}{lllll}
\hline $312-337$ & High & 4 & 629127.20 & 17.91 \\
$337-375$ & very high & 5 & 477357.36 & 13.59 \\
\hline
\end{tabular}

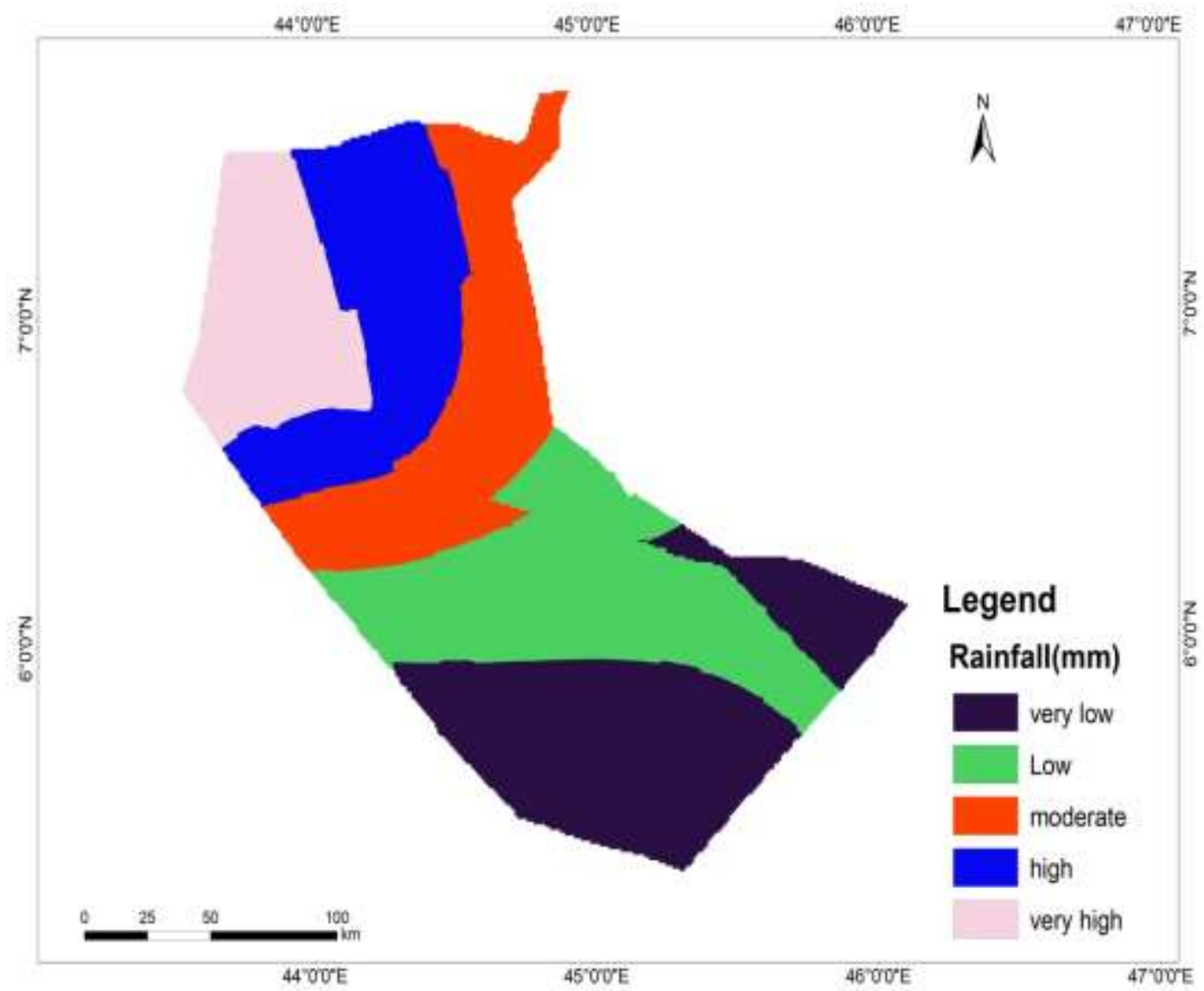

Figure 4.3.Reclassified Rainfall map.

\subsection{Elevation}

With respect to elevation class, the study area has high potential of ground water. This is mainly due to the lower elevation of the area since water tends to store at lower topography instead of the upper topography. Higher the elevation lesser the ground water potential and the other way around (Gedebo, 2005: Vinay, 2015). For this study elevation data having 30meter spatial resolution has been created supported by the ASTER DEM and the result shows around 60\% of the area has very high and high potential of ground water availability followed moderate ground water availability which accounts for $15.28 \%$. An area having low and very low ground water availability is accounted for $13.09 \%$ and $11.80 \%$ respectively.

Table 4.4.Elevation class with respective Ground water availability.

\begin{tabular}{lllll}
\hline Elevation class $(\mathrm{m})$ & $\begin{array}{l}\text { Ground water } \\
\text { availability }\end{array}$ & Value & Area(Ha) & $\begin{array}{l}\text { Area } \\
(\%)\end{array}$ \\
\hline $879-1101$ & very low & 1 & 414702.69 & 11.80 \\
$710-879$ & Low & 2 & 459959.42 & 13.09 \\
$556-710$ & Moderate & 3 & 537038.60 & 15.28 \\
$439-556$ & High & 4 & 1170027.68 & 33.30 \\
$270-439$ & Very high & 5 & 932318.11 & 26.53 \\
\hline
\end{tabular}




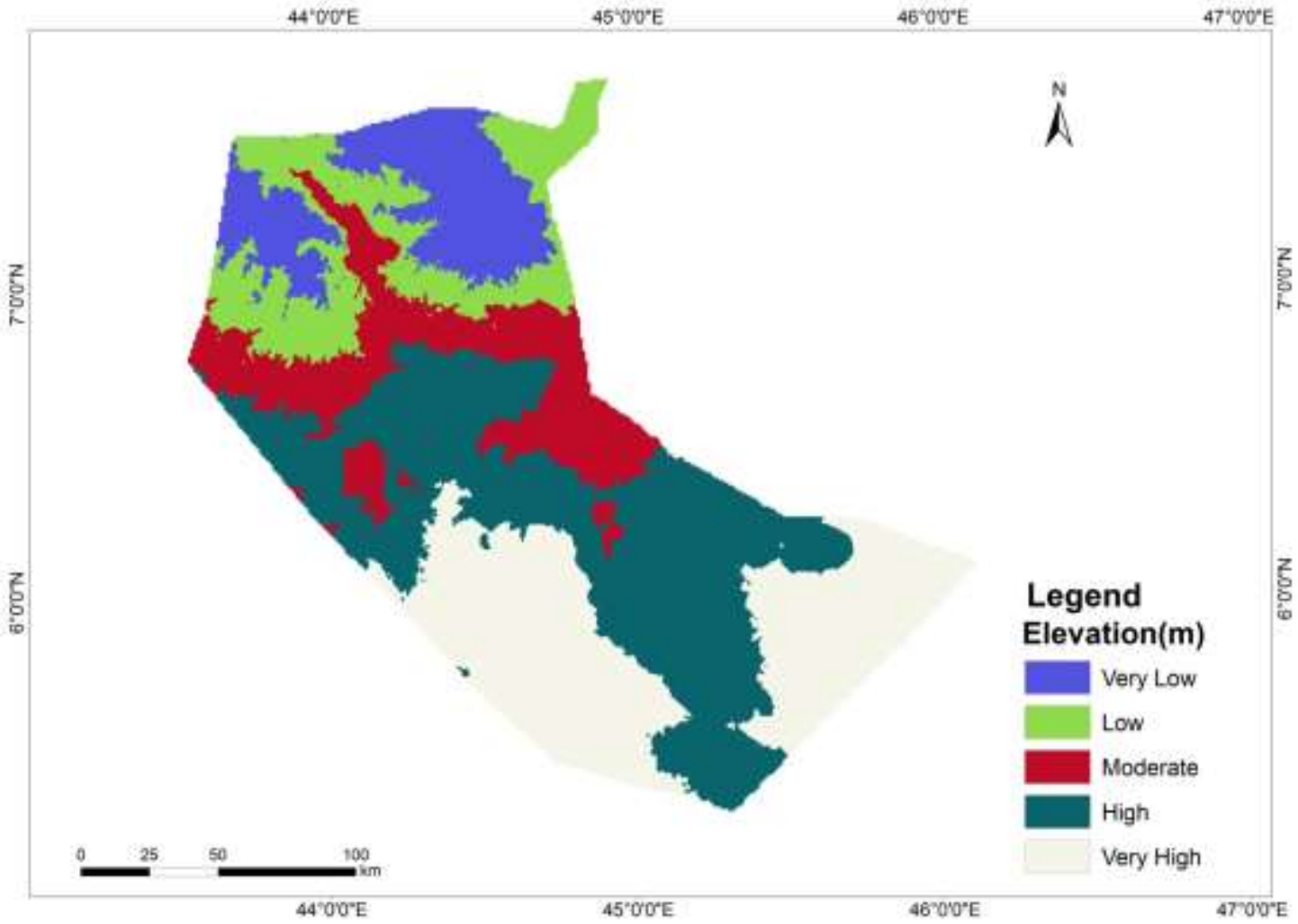

Figure 4.4.Reclassified Elevation map.

\subsection{Slope}

Slope determines the speed of infiltration and runoff of surface water, the flat surface areas can hold and drain the water within the bottom, which might increase the ground water recharge whereas the steep slopes increase the runoff and reduce the infiltration of surface water into ground (Mahalingam and Vinay, 2015). The result of the reclassified slope indicates $70.9 \%$ of the study area has very high potential of ground water availability. Around $18.55 \%$ of the area has high availability of ground water followed by moderate, low and very low which accounts for $7.5 \%, 2.45 \%$ and $0,61 \%$ respectively.

Table 4.5. Reclassified slope class with respective Ground water availability

\begin{tabular}{lllll}
\hline & Ground water & & & \\
Slope class $(\%)$ & availability & Value & Area(Ha) & Area (\%) \\
\hline $11-31$ & very low & 1 & 21476.76 & 0.61 \\
$6-11$ & Low & 2 & 86255.82 & 2.45 \\
3.6 & Moderate & 3 & 263664.56 & 7.50 \\
$1-3$ & High & 4 & 651691.37 & 18.55 \\
$0-1$ & Very High & 5 & 2490957.98 & 70.89 \\
\hline
\end{tabular}




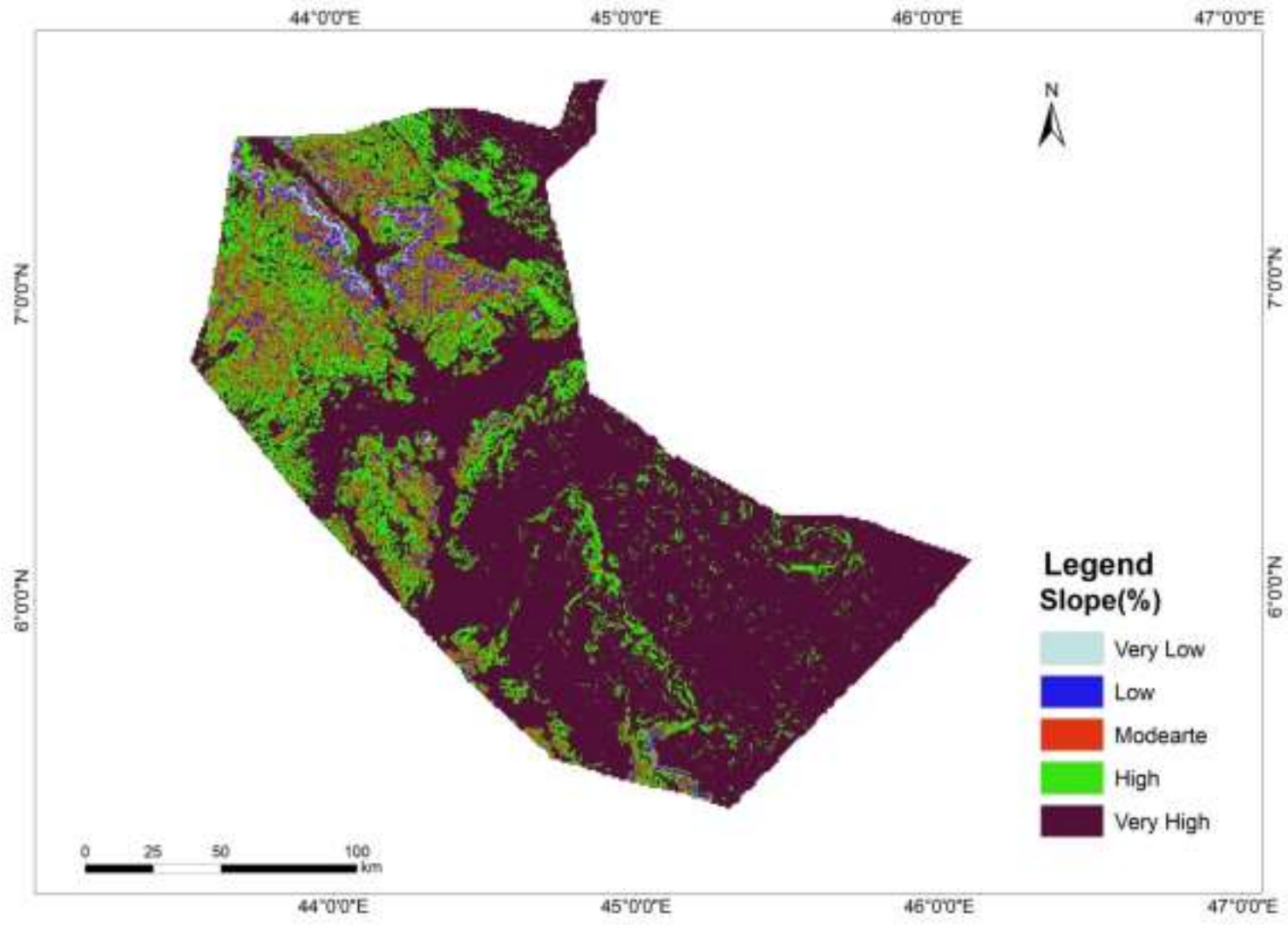

Figure 4.5.Reclassified Slope map.

\subsection{Soil Texture}

Six soil texture class in the study area namely clay, clay loam, loam, sand clay loam, sandy loam and sand were identified. Rank of soil has been assigned on the premise of their infiltration rate. The result indicates $53.34 \%$ of total area of Korahe zone has moderate ground water availability. $30.08 \%$ and $8.07 \%$ of area has low and very low respectively. Only small area $(7.52 \%$ and $1 \%)$ of Korahe zone have very high and high ground water availability.

Table 4.6.Soil texture class with respective Ground water availability.

\begin{tabular}{lllll}
\hline & Ground water & & & \\
Texture class(class) & availability & Value & Area(Ha) & Area $(\%)$ \\
\hline Clay & very low & 1 & 283343.40 & 8.07 \\
Clay loam & Low & 2 & 1056335.82 & 30.08 \\
Loam, sand clay loam & Moderate & 3 & 1873371.41 & 53.34 \\
Sandy loam & High & 4 & 35169.29 & 1.00 \\
Sand & very High & 5 & 264042.50 & 7.52 \\
\hline
\end{tabular}




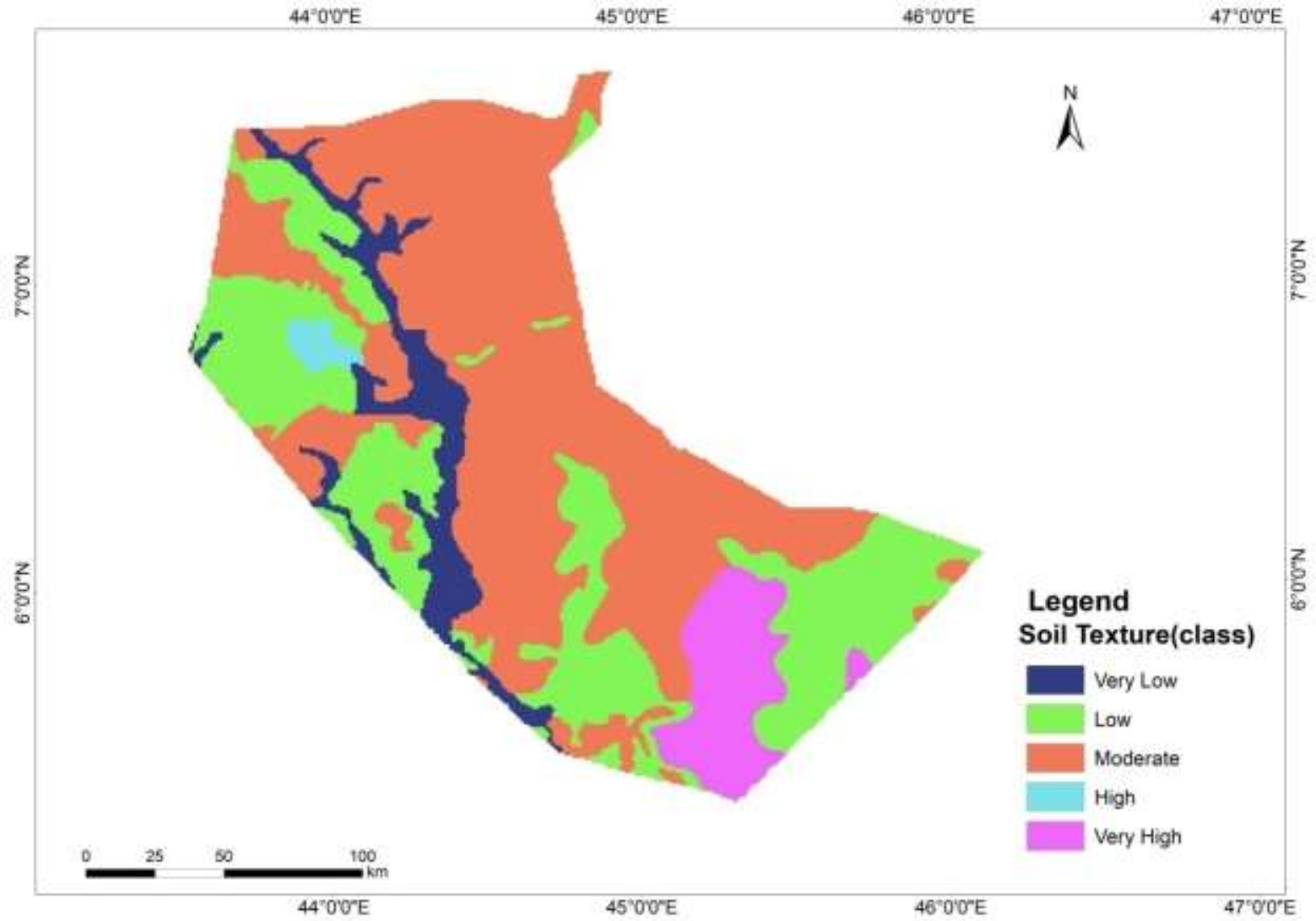

Figure 4.6.Reclassified Soil texture map.

\subsection{Land use and Land cover (LU/LC)}

Land-use/Land-cover plays a vital role in groundwater searching. Land-use type gives the necessary information on infiltration. The rate of recharge, runoff and evapotranspiration are influenced by the type of LU/LC. Land-use/Landcover of the study area was prepared from sentinel-2A using maximum likelihood classification technique with the integration of field and google earth verification. The type of LU/LC includes Trees cover areas, Shrubs cover areas, Grassland, Cropland, Vegetation aquatic or regularly flooded, Lichen Mosses / Sparse vegetation ,Bare areas, Built up areas and Open water (Figure 4.7). From the total study area, Grassland covers most of the area and water body covers small area relative to others (Table 4.7).

To classify land use/cover, and its accuracy, it needs another sample size and the training sites and representative samples for accuracy assessment from each land use/cover class was also selected using random sampling. According to Congalton (2009), at least 30 sample points per class are preferred for accuracy assessment, even if, collecting reference samples, especially ground survey locations, can be extremely expensive. For most positional accuracy assessments minimum of 30 samples per land use/cover class were taken to assess accuracy of land use/cover classification of this study. Therefore, the sample size to assess accuracy of land use/cover was = LU/C Class $* 30$ for the purpose of this study. These points were checked in two ways; those that were accessible and observed in the field and the second means were using Google Earth as a reference. Accordingly, the following error matrix (Table 4.8) for the 270 sample points is presented.

Table 4.7: Land-use/Land-cover types and coverage of the study area

\begin{tabular}{lll}
\hline LU/LC class & Area(ha) & Area (\%) \\
\hline Trees cover area & 41900.76 & 1.193593 \\
Shrubs cover areas & 1546121 & 44.04309 \\
Grassland & 1772569 & 50.49375 \\
Cropland & 122618.4 & 3.49293 \\
\hline
\end{tabular}




\begin{tabular}{lll}
\hline Vegetation aquatic or regularly flooded & 404.396 & 0.01152 \\
Lichen Mosses / Sparse vegetation & 20631.36 & 0.587709 \\
Bare areas & 5772.154 & 0.164427 \\
Built up areas & 436.1882 & 0.012425 \\
Open water & 19.4126 & 0.000553 \\
\hline
\end{tabular}

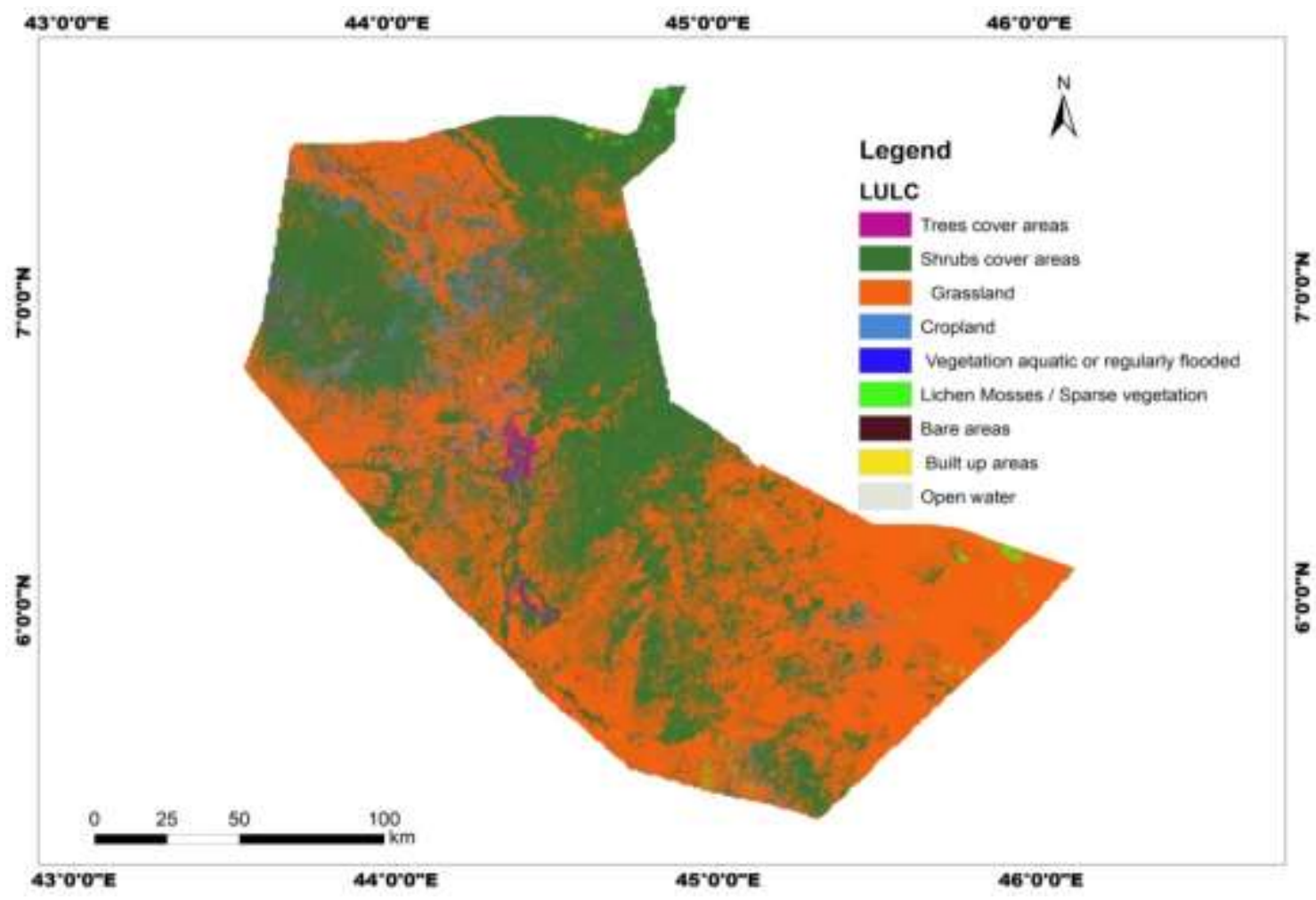

Figure 4.7 LULC cover of the study area

Table 4.8: Accuracy assessment

Reference (GPS) Data

\begin{tabular}{|c|c|c|c|c|c|c|c|c|c|c|c|}
\hline 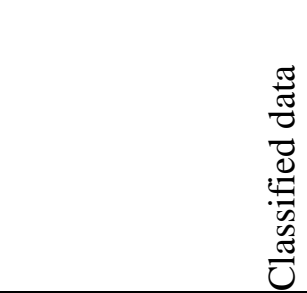 & 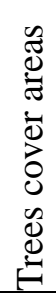 & 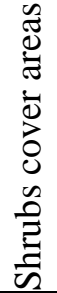 & $\begin{array}{l}\vec{\Xi} \\
\frac{\pi}{\tilde{D}} \\
\tilde{\Xi} \\
\tilde{0}\end{array}$ & 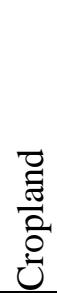 & 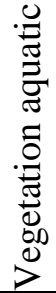 & 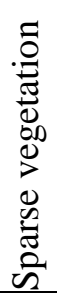 & 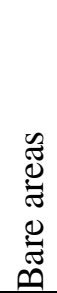 & 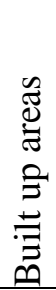 & $\begin{array}{l}\bar{\Phi} \\
\overline{\tilde{z}} \\
\tilde{z} \\
\tilde{0} \\
\tilde{0}\end{array}$ & $\stackrel{\tilde{0}}{0}$ & 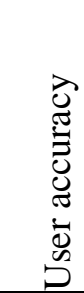 \\
\hline Trees cover areas & 27 & 0 & 0 & 0 & 0 & 6 & 0 & 0 & 0 & 33 & 81.8 \\
\hline Shrubs cover areas & 0 & 29 & 2 & 0 & 0 & 0 & 0 & 0 & 0 & 31 & 93.5 \\
\hline Grassland & 0 & 1 & 27 & 0 & 0 & 3 & 0 & 0 & 0 & 31 & 87.1 \\
\hline Cropland & 0 & 0 & 1 & 26 & 0 & 0 & 4 & 3 & 0 & 34 & 76.5 \\
\hline Vegetation aquatic & 1 & 0 & 0 & 0 & 28 & 1 & 0 & 0 & 3 & 33 & 84.8 \\
\hline Sparse vegetation & 2 & 0 & 0 & 0 & 0 & 19 & 0 & 0 & 0 & 21 & 90.5 \\
\hline Bare areas & 0 & 0 & 0 & 4 & 0 & 1 & 24 & 2 & 0 & 31 & 77.4 \\
\hline Built up areas & 0 & 0 & 0 & 0 & 0 & 0 & 2 & 25 & 0 & 27 & 92.6 \\
\hline
\end{tabular}




\begin{tabular}{rrrrrrrrrrrr} 
Open water & 0 & 0 & 0 & 0 & 2 & 0 & 0 & 0 & 27 & 29 & 93.1 \\
Total & 30 & 30 & 30 & 30 & 30 & 30 & 30 & 30 & 30 & 270 & \\
Producer accuracy & 90.0 & 96.7 & 90.0 & 86.7 & 93.3 & 63.3 & 80.0 & 83.3 & 90.0 & & \\
\hline
\end{tabular}

The overall accuracy and kappa analysis were used to perform a classification accuracy assessment and accordingly over all accuracy of the data is $86 \%$ and kappa coefficient was computed which is 0.84 and from the result the interpretation can be taken as accurate result for further analysis. The occurrence of groundwater is affected by the type of LU/LC. Considering this, LU/LC of the study area reclassified into five (Table 4.9 and Figure 4.8) as per suitability rank of recharge information.

Table 4.9.LULC class with respective Ground water availability.

\begin{tabular}{llrrr}
\hline & Ground water & & & \\
LULC class & availability & value & \multicolumn{1}{l}{ Area(Ha) } & \multicolumn{1}{c}{ Area $(\%)$} \\
\hline Bare land, Built-up area & very low & 1 & 6205.59 & 0.18 \\
Shrubs area & Low & 2 & 1544249.84 & 43.99 \\
Grassland, cropland & Moderate & 3 & 1897143.34 & 54.04 \\
Tree cover, sparse vegetation & High & 4 & 62854.43 & 1.79 \\
Open water & very High & 5 & 19.41 & 0.0005691 \\
\hline
\end{tabular}

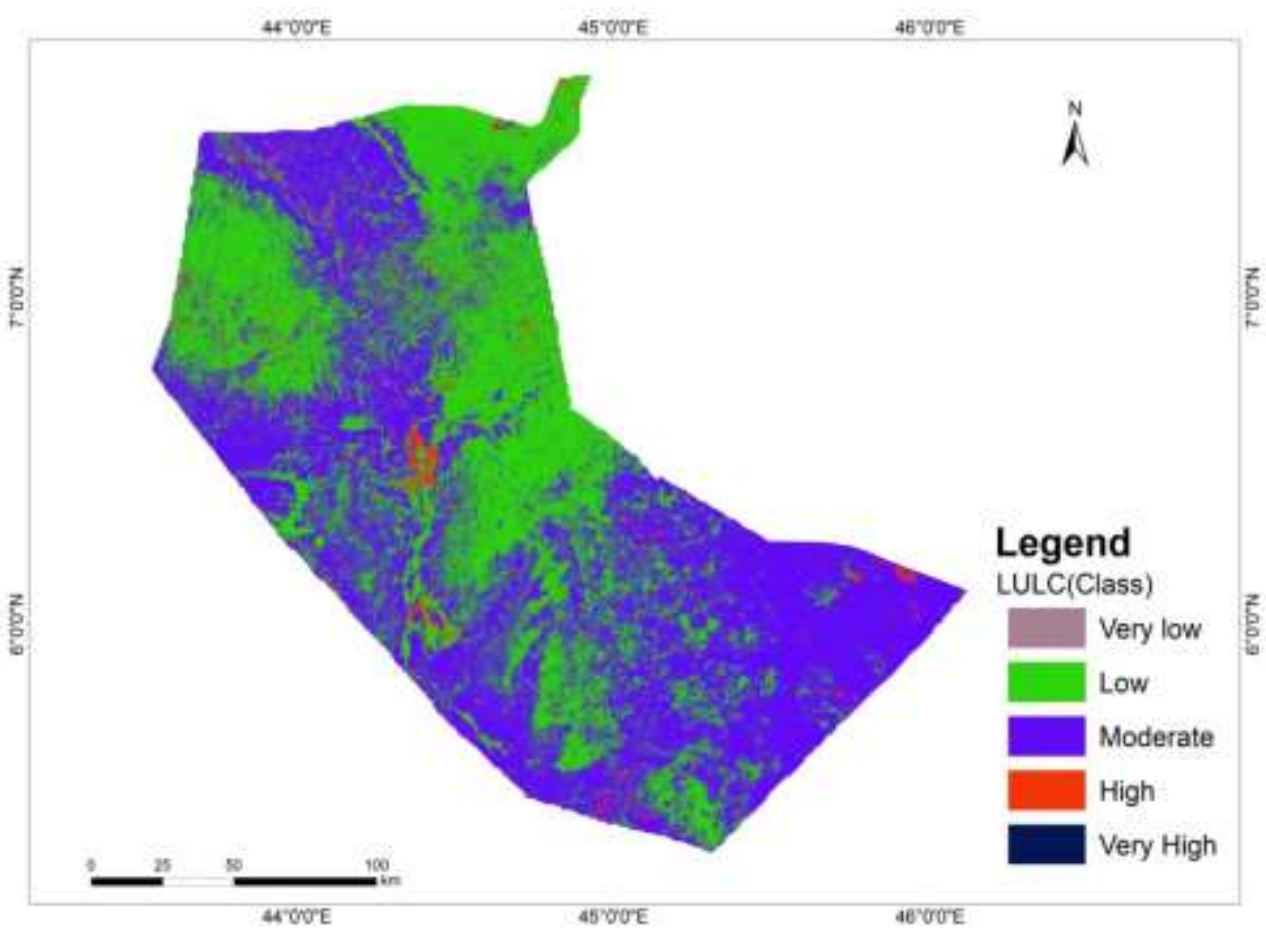

Figure 4.8.Reclassified LULC map.

\subsection{Geomorphology}

With respect to geomorphology, majority of the study area have high ground water availability (69.73\%). Area having moderate ground water availability is accounts for $29.80 \%$. This result shows there are only few significant areas of Korahe zone which have very high, low and very low water availability.

Table 4.10 Geomorphology class with respective Ground water availability.

\begin{tabular}{lllll}
\hline Geomorphology class & Ground water & Value & Area(Ha) & Area (\%) \\
\hline
\end{tabular}




\begin{tabular}{llrrr}
\hline & availability & & & \\
\hline Hills & very low & 1 & 2802.12 & 0.08 \\
Complex Landforms & Low & 2 & 13712.29 & 0.39 \\
Foot slopes, Bad Lands \&Piedmont Plains & Moderate & 3 & 1045292.82 & 29.80 \\
Plains Valleys/Minor Valleys & High & 4 & 2445881.33 & 69.73 \\
\hline
\end{tabular}

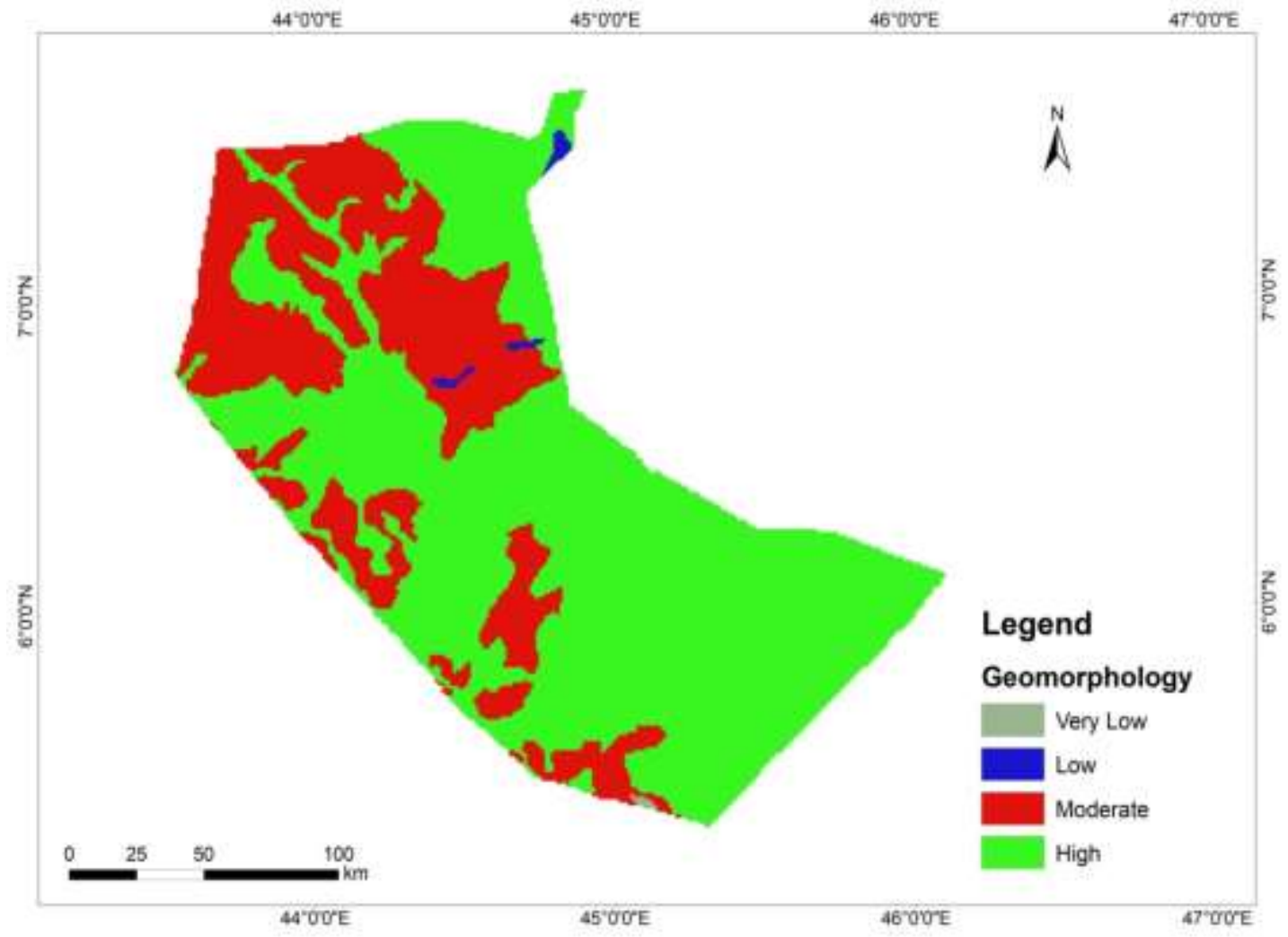

Figure 4.9.Reclassified Geomorphology map.

\section{9 .Geology}

The result of the geological features of the study area which is classified in terms of groundwater potentiality indicates $63.02 \%$ of the study area has high ground water availability. Very high and very low ground water availability accounts for $10.04 \%$ and $26.94 \%$ respectively.

Table 4.11.Geology class with respective Ground water availability.

\begin{tabular}{llrrr}
\hline & $\begin{array}{l}\text { Ground } \\
\text { water } \\
\text { availability }\end{array}$ & value & Area(Ha) & Area(\%) \\
\hline Geology class & very low & 1 & 945021.11 & 26.94 \\
\hline Basic and ultrabasic rocks/Undifferentiated igneous rocks & High & 4 & 2210231.24 & 63.02 \\
\hline $\begin{array}{l}\text { Crystalline limestones/Marls (calcareous } \\
\text { mudstones)/Grains, relatively rich sandstones }\end{array}$ & Hery high & 5 & 352150.55 & 10.04 \\
\hline $\begin{array}{l}\text { Undifferentiated unconsolidated sediments/Cover sands } \\
\text { (Aeolian deposits etc.) }\end{array}$ & very
\end{tabular}




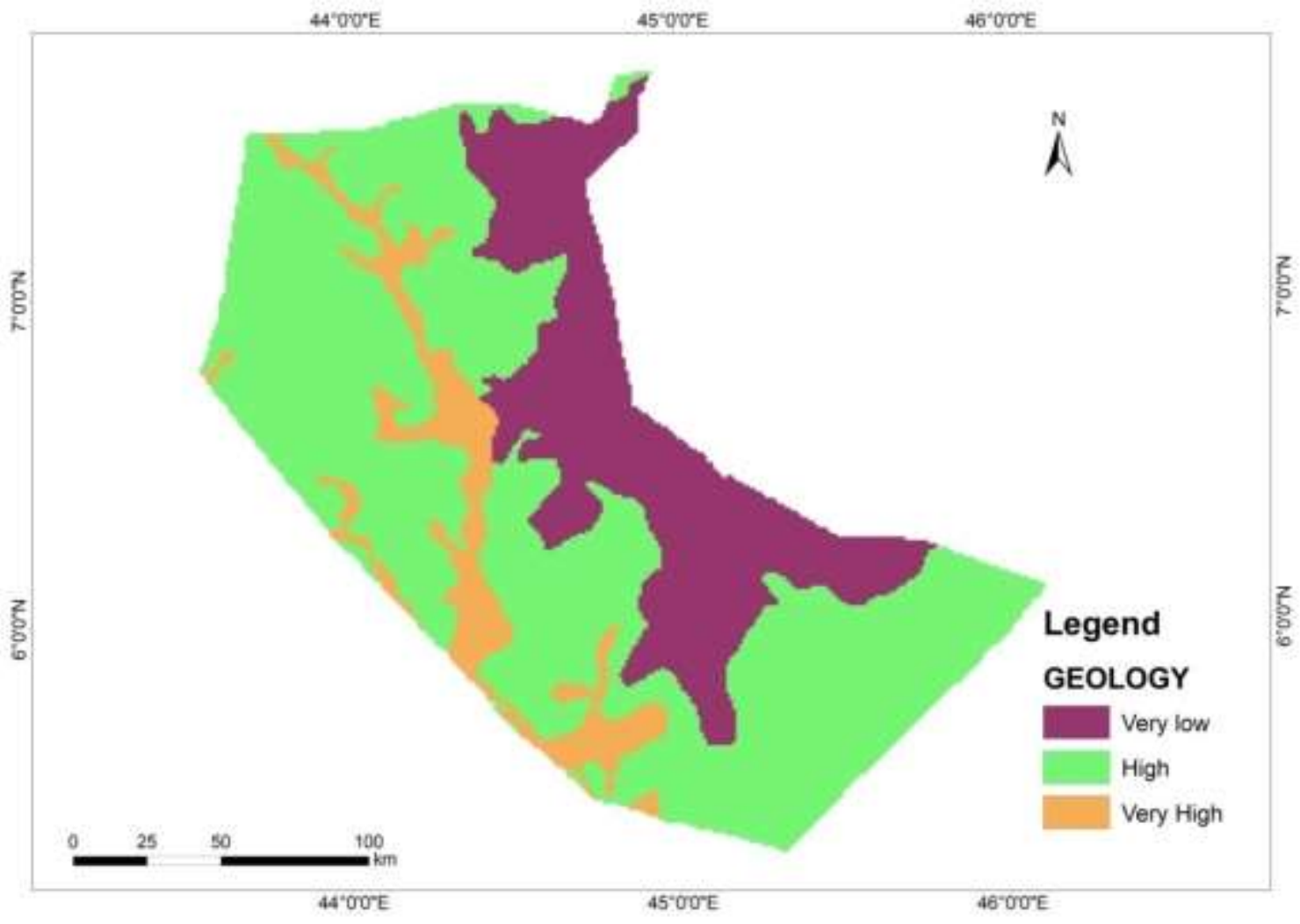

Figure 4.10 .Reclassified Geology map.

\subsection{Weight assignment to parameters}

The selected parameters are prepared and classified in the GIS environment, and then the weight of each parameter and its class is assigned through the analysis and layering process. Finally, the weighted overlay analysis is usually performed in ArcGIS to find the results. Based on the IDIRISI_AHP weight derivation module, the following eigenvector weights for all criteria considered for groundwater potential zone selection were generated (Table 4.12).In summary, the results of the AHP weight derivation reveals that parenthetically, lineament density plays an important role with the best score weight of $30.7 \%$ followed by soil texture, LULC, Geomorphology, Geology, Rainfall, drainage density, elevation and slope with score weight of $21.8 \%, 15.4 \%, 10.9 \%, 7.64 \%, 5.33 \%, 3.7 \%, 2.59 \%$ and $1.89 \%$, respectively. A region having high lineament density was given high weight and the other way around (Ibrahim-Bathis and Ahmed, 2016; Naghibi et al., 2017). A part having high drainage density was assigned very low weight (Tolche, 2020; Andualem \& Demeke, 2019 ;) whereas steep slope area assigned to low weight (Hussein et al., 2016).

Table 4.12. Pair-wise comparison matrix

\begin{tabular}{|c|c|c|c|c|c|c|c|c|c|}
\hline Criteria & 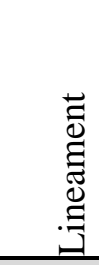 & 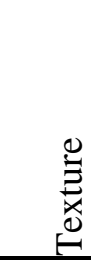 & $\begin{array}{l}U \\
\\
\end{array}$ & $\begin{array}{l}\text { bे } \\
\frac{0}{0} \\
\frac{0}{2} \\
0 \\
0 \\
0 \\
0 \\
0\end{array}$ & $\begin{array}{l}\overrightarrow{0 D} \\
\frac{0}{0} \\
0 \\
0\end{array}$ & 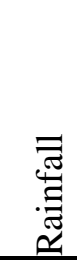 & 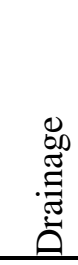 & 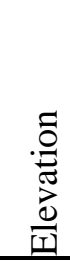 & $\frac{0}{\tilde{0}}$ \\
\hline Lineament & 1 & 2 & 3 & 4 & 5 & 6 & 7 & 8 & 9 \\
\hline Texture & 0.5 & 1 & 2 & 3 & 4 & 5 & 6 & 7 & 8 \\
\hline LULC & 0.33 & 0.5 & 1 & 2 & 3 & 4 & 5 & 6 & 7 \\
\hline Geomorphology & 0.25 & 0.33 & 0.5 & 1 & 2 & 3 & 4 & 5 & 6 \\
\hline Geology & 0.2 & 0.25 & 0.33 & 0.5 & 1 & 2 & 3 & 4 & 5 \\
\hline Rainfall & 0.17 & 0.2 & 0.25 & 0.3 & 0.5 & 1 & 2 & 3 & 4 \\
\hline
\end{tabular}




\begin{tabular}{lccccccccc}
\hline Drainage & 0.14 & 0.17 & 0.2 & 0.3 & 0.3 & 0.5 & 1 & 2 & 3 \\
Elevation & 0.13 & 0.14 & 0.17 & 0.2 & 0.3 & 0.33 & 0.5 & 1 & 2 \\
Slope & 0.11 & 0.13 & 0.14 & 0.2 & 0.2 & 0.25 & 0.33 & 0.5 & 1 \\
Sum & 2.83 & 4.72 & 7.59 & 12 & 16 & 22.1 & 28.8 & 37 & 45 \\
\hline
\end{tabular}

Table 4.13. Normalized pair-wise comparison matrix

\begin{tabular}{|c|c|c|c|c|c|c|c|c|c|c|c|}
\hline Criteria & 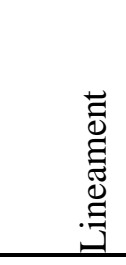 & 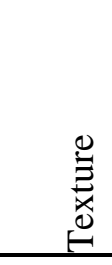 & $\stackrel{U}{S}$ & $\begin{array}{l}\text { 이 } \\
\circ \\
0 \\
0 \\
0 \\
0 \\
0 \\
0 \\
0 \\
0 \\
0\end{array}$ & $\begin{array}{l}\text { के० } \\
0 \\
0 \\
0 \\
0 \\
0\end{array}$ & $\begin{array}{l}\bar{\Xi} \\
\stackrel{\Xi}{\Xi} \\
\underline{\Xi} \\
\end{array}$ & 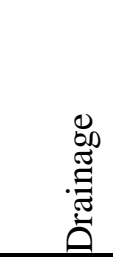 & 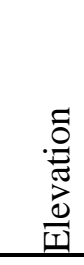 & $\frac{0}{\frac{0}{2}}$ & $\begin{array}{l}\vec{E} \\
.00 \\
z\end{array}$ & $0^{\circ}$ \\
\hline Lineament & 0.35 & 0.42 & 0.4 & 0.35 & 0.31 & 0.27 & 0.24 & 0.2 & 0.2 & 0.31 & 30.7 \\
\hline Texture & 0.18 & 0.21 & 0.26 & 0.26 & 0.25 & 0.23 & 0.21 & 0.2 & 0.2 & 0.22 & 21.8 \\
\hline LULC & 0.12 & 0.11 & 0.13 & 0.17 & 0.18 & 0.18 & 0.17 & 0.2 & 0.2 & 0.15 & 15.4 \\
\hline Geomorphology & 0.09 & 0.07 & 0.07 & 0.09 & 0.12 & 0.14 & 0.14 & 0.1 & 0.1 & 0.11 & 10.9 \\
\hline Geology & 0.07 & 0.05 & 0.04 & 0.04 & 0.06 & 0.09 & 0.1 & 0.1 & 0.1 & 0.08 & 7.64 \\
\hline Rainfall & 0.06 & 0.04 & 0.03 & 0.03 & 0.03 & 0.05 & 0.07 & 0.1 & 0.1 & 0.05 & 5.33 \\
\hline Drainage & 0.05 & 0.04 & 0.03 & 0.02 & 0.02 & 0.02 & 0.03 & 0.1 & 0.1 & 0.04 & 3.7 \\
\hline Elevation & 0.04 & 0.03 & 0.02 & 0.02 & 0.02 & 0.02 & 0.02 & 0 & 0 & 0.03 & 2.59 \\
\hline Slope & 0.04 & 0.03 & 0.02 & 0.01 & 0.01 & 0.01 & 0.01 & 0 & 0 & 0.02 & 1.89 \\
\hline
\end{tabular}

Table4.14. CI and CR worksheet

\begin{tabular}{|c|c|c|c|c|c|c|c|c|c|c|c|}
\hline Criteria & 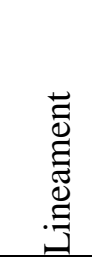 & 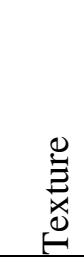 & 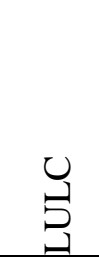 & $\begin{array}{l}\overrightarrow{0} 0 \\
\frac{0}{0} \\
0 \\
\frac{0}{2} \\
0 \\
0 \\
0 \\
0 \\
0\end{array}$ & $\begin{array}{l}\text { 盛 } \\
\frac{0}{0} \\
0 \\
0\end{array}$ & 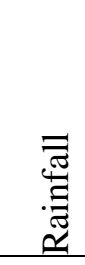 & 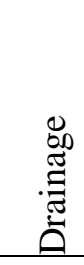 & 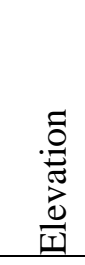 & $\frac{\ddot{a}}{\frac{\pi}{n}}$ & $\begin{array}{l}\Xi \\
\Xi \\
\Xi\end{array}$ & 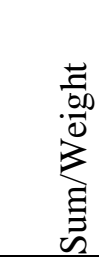 \\
\hline Lineament & 0.31 & 0.44 & 0.46 & 0.44 & 0.38 & 0.46 & 0.26 & 0.21 & 0.17 & 3.12 & 10.16 \\
\hline Texture & 0.15 & 0.22 & 0.31 & 0.33 & 0.31 & 0.27 & 0.22 & 0.18 & 0.15 & 2.13 & 9.78 \\
\hline LULC & 0.1 & 0.11 & 0.15 & 0.22 & 0.23 & 0.21 & 0.19 & 0.16 & 0.13 & 1.5 & 9.72 \\
\hline Geomorphology & 0.08 & 0.07 & 0.08 & 0.11 & 0.15 & 0.16 & 0.15 & 0.13 & 0.11 & 1.04 & 9.55 \\
\hline Geology & 0.06 & 0.05 & 0.05 & 0.05 & 0.08 & 0.11 & 0.11 & 0.1 & 0.09 & 0.71 & 9.34 \\
\hline Rainfall & 0.05 & 0.04 & 0.04 & 0.04 & 0.04 & 0.05 & 0.07 & 0.08 & 0.08 & 0.49 & 9.17 \\
\hline Drainage & 0.04 & 0.04 & 0.03 & 0.03 & 0.03 & 0.03 & 0.04 & 0.05 & 0.06 & 0.34 & 9.08 \\
\hline Elevation & 0.04 & 0.03 & 0.03 & 0.02 & 0.02 & 0.02 & 0.02 & 0.03 & 0.04 & 0.24 & 9.1 \\
\hline \multirow[t]{5}{*}{ Slope } & 0.03 & 0.03 & 0.02 & 0.02 & 0.02 & 0.01 & 0.01 & 0.01 & 0.02 & 0.17 & 9.22 \\
\hline & & & & & & & & & & $\lambda \max$ & 9.46 \\
\hline & & & & & & & & & & CI & 0.05 \\
\hline & & & & & & & & & & RI & 1.45 \\
\hline & & & & & & & & & & $\mathrm{CR}$ & 0.039 \\
\hline
\end{tabular}




\subsection{Delineation of groundwater potential zones}

Groundwater potential zones of Korahe zone were delineated by integrating all the thematic maps. After the weightage of each parameter has been determined, a spatial overlay method in Arc GIS environment is employed to conduct overly analysis to get the intended result. The results of overlay analysis has been classified into five classes as very low, low, moderate, high and very high (figure 4.11). The results of the reclassified thematic map found that, about 169631.71 ha $(4.89 \%)$ areas have very high, 334818.58ha $(9.65 \%)$ area have high, 587658.05ha (16.93\%) have moderate, 1194164.18ha (34.41\%) have low and $1184005.67 \mathrm{ha}(34.12 \%)$ area are have very low potential of ground water (Table 4.15). Very high and high groundwater potential zones are concentrated within the area where, high lineament density was illustrated of the basic factors for groundwater potential zonation (Ibrahim-Bathis\& Ahmed, 2016).The low to very low potential zones are mainly distributed within the areas having high drainage density. Hence, the groundwater potential in these areas may be not sufficient for irrigation and other livelihood requirements. Therefore, groundwater development activities preferred to be performed in high groundwater prospective zones.

Table 4.15.Groundwater potential area and percentage of the study area.

\begin{tabular}{cccc}
\hline Ground water availability & Value & Area (ha) & Area (\%) \\
\hline very low & 1 & 1184005.67 & 34.12 \\
Low & 2 & 1194164.18 & 34.41 \\
Moderate & 3 & 587658.05 & 16.93 \\
High & 4 & 334818.58 & 9.65 \\
very high & 5 & 169631.71 & 4.89 \\
\hline
\end{tabular}

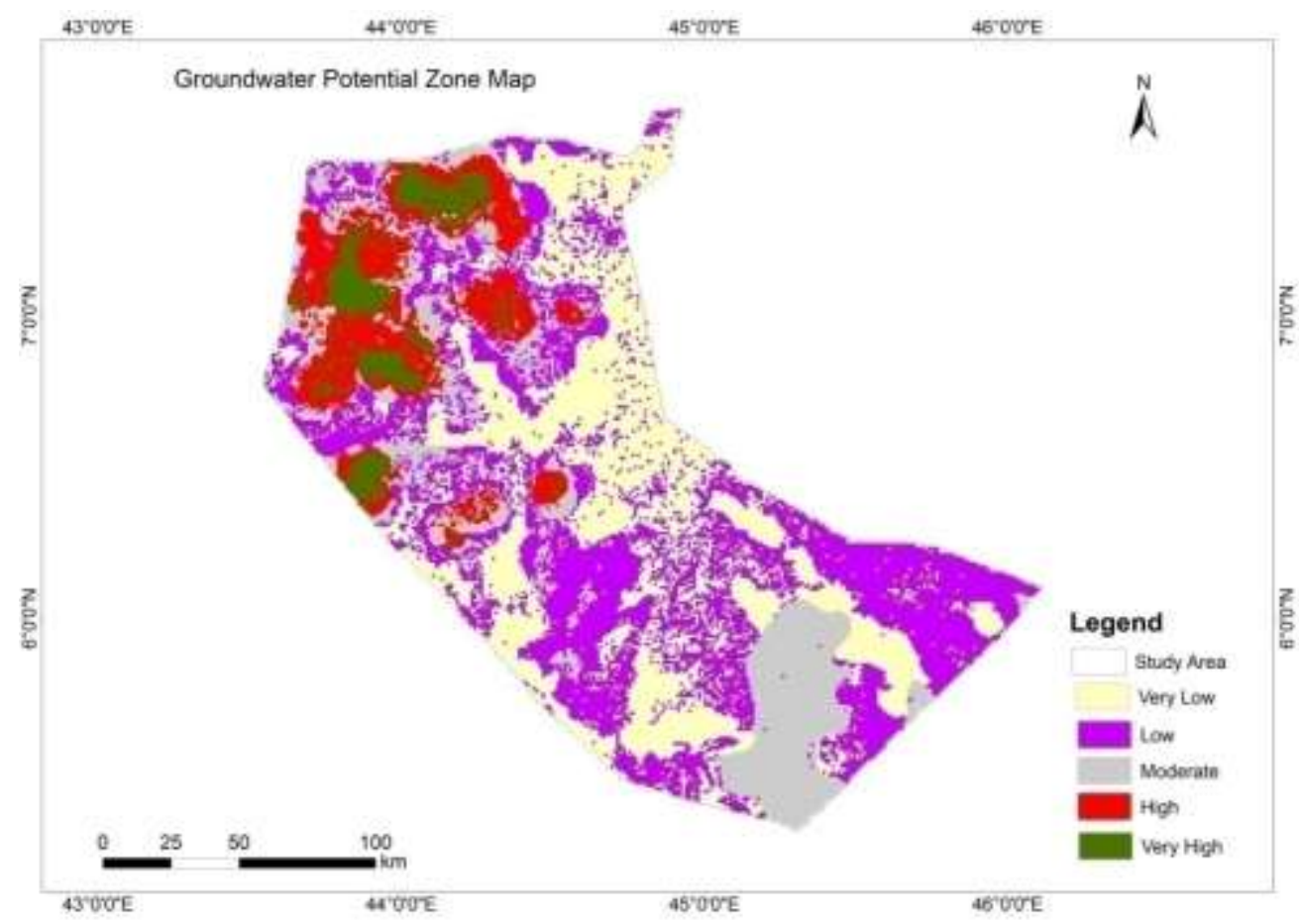

Figure 4.11 Groundwater Potential zones of map of Korahe zone

\section{Conclusion}

The study focused on groundwater potential zone mapping through integration and weightage overlay analysis in GIS environment using physical parameters. The methodology begins with the preparation of thematic layers from different data sources and next deriving the weights using overlay analysis to search out groundwater potential. The weightage is assigned to different layers and overlaid to realize the intended result groundwater potential zones of Korahe zone. First, 
assign weights to the thematic layers to support the precise importance of the categories in each parameter. These layers are then overlaid and classified into five categories that support groundwater availability; very high, high and moderate, low and very low. The study found that, about 169631.71 ha $(4.89 \%)$ areas have very high, 334818.58 ha $(9.65 \%)$ area have high, 587658.05ha (16.93\%) have moderate, 1194164.18ha (34.41\%) have low and 1184005.67ha (34.12\%) area have very low potential of ground water. The integration of GIS and Remote sensing technique in ground water analysis from various thematic maps proves to be very important to map the groundwater occurrence and movement for recharge potential mapping and management plan on a scientific basis in the study area.

\section{References}

Abdulahi, A., Wudad, A., \&Babege, K. (2020).Invasion of ProsopisJuliflora and Its Impact on Pastoralists' Livelihoods in Korahey Zone of Somali Regional State, Ethiopia. Journal of the Social Sciences, 48(4).

Allafta, H., Opp, C., \& Patra, S. (2021). Identification of Groundwater Potential Zones Using Remote Sensing and GIS Techniques: A Case Study of the Shatt Al-Arab Basin. Remote Sensing, 13(1), 112.

Andualem, T. G., \&Demeke, G. G. (2019). Groundwater potential assessment using GIS and remote sensing: A case study of Guna tana landscape, upper Blue Nile Basin, Ethiopia. Journal of Hydrology: Regional Studies, 24, 100610 .

Arshad, A.; Zhang, Z.; Zhang, W.; Dilawar, A (2020).Mapping favorable groundwater potential recharge zones using a GIS-based analytical hierarchical process and probability frequency ratio model: A case study from an agro-urban region of Pakistan.Geosci.

Arumaikkani, G. S., Chelliah, S., \&Gopalan, M. (2017). Revelation of groundwater possible region using fuzzy logic based GIS modeling. International Journal of Applied Engineering Research, 12(22), 12176-12183.

Aryanto, D. E., \&Hardiman, G. (2018). Assessment of groundwater recharge potential zone using GIS approach in Purworejo regency, Central Java province, Indonesia. In E3S Web of Conferences (Vol. 31, p. 12002).EDP Sciences.

Badamasi, S., Sawa, B. A., \&Garba, M. L. (2016).Groundwater potential zones mapping using remote sensing and geographic information system techniques (GIS) in Zaria, Kaduna state, Nigeria. American Scientific Research Journal for Engineering, Technology, and Sciences (ASRJETS), 24(1), 51-62.

Barik, K. K., Dalai, P. C., Goudo, S. P., Panda, S. R., \& Nandi, D. (2017). Delineation of groundwater potential zone in Baliguda Block of Kandhamal District, Odisha using geospatial technology approach. Int J Adv Remote Sens GIS, 6(3), 2068-2079.

Bereket, B.(2017). "Groundwater Potential Mapping Using Remote Sensing and GIS in Rift Valley Lakes Basin, Weito Sub Basin, Ethiopia." International Journal of Scientific \& Engineering Research 8(2): 43-50. http://www.ijser.org.

Berhanu, B., Seleshi, Y., \&Melesse, A. M. (2014). Surface water and groundwater resources of Ethiopia: potentials and challenges of water resources development. In Nile River Basin (pp. 97-117).Springer, Cham.

Bozdağ, A., Yavuz, F., \&Günay, A. S. (2016). AHP and GIS based land suitability analysis for Cihanbeyli (Turkey) County. Environmental Earth Sciences, 75(9), 813.

Congalton, R. G. (2009). Accuracy and error analysis of global and local maps: Lessons learned and future considerations. Remote Sensing of Global Croplands for Food Security, 441, 47-55.

Dar, T.; Rai, N.; Bhat, A.(202). Delineation of potential groundwater recharge zones using analytical hierarchy process (AHP). Geol. Ecol. Landsc. 2020.

Das, B.; Pal, S.; Malik, S.; Chakrabortty, R.(2018).Modeling groundwater potential zones of Puruliya district, West Bengal, India using remote sensing and GIS techniques.Geol. Ecol. Landsc, 3, 223-237 
Effat, H. A., \& Hassan, O. A. (2013). Designing and evaluation of three alternatives highway routes using the Analytical Hierarchy Process and the least-cost path analysis, application in Sinai Peninsula, Egypt. The Egyptian Journal of Remote Sensing and Space Science, 16(2), 141-151.

Falah, F.; GhorbaniNejad, S.; Rahmati, O.; Daneshfar, M.; Zeinivand, H. (207). Applicability of generalized additive model in groundwater potential modelling and comparison its performance by bivariate statistical methods, GeocartoInt, 32, 1069-1089.

Fashae, O. A., et al. (2014). Delineation of Groundwater Potential Zones in the Crystalline Basement Terrain of SWNigeria: An Integrated GIS and Remote Sensing Approach. Applied Water Science, 4, pp. 19 - 38.

Ghodratabadi, S., \&Feizi, F. (2015). Identification of groundwater potential zones in Moalleman, Iran by remote sensing and index overlay technique in GIS. Iranian Journal of Earth Sciences, 7(2), 142-152.

Hashim, M., Ahmad, S., Johari, M. M., \& Pour, A. B. (2013). Automatic lineament extraction in a heavily vegetated region using Landsat Enhanced Thematic Mapper (ETM+) imagery. Advances in Space Research, 51(5), 874890.

Ibrahim-Bathis, K., \& Ahmed, S. A. (2016).Geospatial technology for delineating groundwater potential zones in Doddahalla watershed of Chitradurga district. India. The Egyptian Journal of Remote Sensing and Space Sciences, 19(2), 223-234.

Jeyapprabha, R., Revathy, S. S., \&Sureshbabu, S. (2014). Study on landuse pattern to evaluate groundwater potential zone for Bengaluru urban area using RS \& GIS techniques. Int J ComputSci Inform Technol, 5(2), 1213-1218.

Kumar, V.; Mondal, N.; Ahmed, S. (2020). Identification of Groundwater Potential Zones Using RS, GIS and AHP Techniques: A Case Study in a Part of Deccan Volcanic Province (DVP), Maharashtra, India. J. Indian Soc. Remote Sens, 48, 497-511.

Machiwal, D.; Madan, K.; Jha, M.; Bimal, C.; Mal, B.(2011).Assessment of groundwater potential in a semi-arid region of India using remote sensing, GIS and MCDM techniques.Water Resour. Manag, 25, 1359-1386.

Magesh, N.; Chandrasekar, N.; Soundranayagam, J.(2012). Delineation of groundwater potential zones in Theni district, Tamil Nadu, using remote sensing, GIS and MIF techniques.Geosci, 3, 189-196.

Mahalingam, B., \& Vinay, M. (2015). Identification of ground water potential zones using GIS and Remote Sensing Techniques: A case study of Mysore taluk-Karnataka. International journal of Geomatics and Geosciences, 5(3), 393-403.

Malczewski, J.(2006) GIS-based multicriteria decision analysis: A survey of the literature. Int. J. Geogr. Inf. Sci, 20, 703726.

Mallick, J.; Khan, R.; Ahmed, M.; Alqadhi, S.; Alsubih, M.; Falqi, I.; Abul Hasan, M.(2019).Modeling Groundwater Potential Zone in a Semi-Arid Region of Aseer Using Fuzzy-AHP and Geoinformation Techniques.Water, 11, 2656.

Mukherjee, P., Singh, C.K., Mukherjee, S., (2012). Delineation of groundwater potential zones in arid region of India-a remote sensing and GIS approach. Water Resour. Manag. 26 (9), 2643-2672.

Murasingh, S., \&Jha, R. (2013). Identification of groundwater potential zones using remote sensing and GIS in a mine area of Odisha. In Makalahdisajikandalam National Conference on Recent Approaches To Water Resource Management, Dhanbad, India: Indian School of Mines.

Naghibi, S. A., Moghaddam, D. D., Kalantar, B., Pradhan, B., \& Kisi, O. (2017). A comparative assessment of GIS-based data mining models and a novel ensemble model in groundwater well potential mapping. Journal of Hydrology, $548,471-483$.

Nampak, H., Pradhan, B., \&Manap, M. A. (2014). Application of GIS based data driven evidential belief function model to predict groundwater potential zonation. Journal of Hydrology, 513, 283-300.

Nasir, M.; Khan, S.; Zahid, H.; Khan, A.(2018). Delineation of groundwater potential zones using GIS and multi influence factor (MIF) techniques: A study of district Swat, Khyber Pakhtunkhwa, Pakistan. Environ. Earth Sci., $77,367$. 
Oboko, H., Jana, S. K., \&Sekac, T. (2021). Spatial Assessment of Groundwater Potential Zones of East New Britain province, Papua New Guinea. PalArch's Journal of Archaeology of Egypt/Egyptology, 18(4), 6021-6042.

Puertas, DG et al. 2015. "Status and Potential of Groundwater Use in Ethiopian Floodplains.": 1-24. www.spateirrigation.org.

Rahmati, O., Samani, A.N., Mahdavi, M., Pourghasemi, H.R., Zeinivand, H., (2015).Groundwater potential mapping at Kurdistan region of Iran using analytic hierarchy process and GIS.Arab. J. Geosci. 8 (9), 7059-7071.

Rajaveni, S.P., Brindha, K., Elango, L., (2017). Geological and geomorphological controls on groundwater occurrence in a hard rock region.Appl. Water Sci. 7 (3), 1377-1389.

Saaty, T. (1980). The analytic hierarchy process (AHP) for decision making. In Kobe, Japan.

Saranya, T.; Saravanan, S.(2020).Groundwater potential zone mapping using analytical hierarchy process (AHP) and GIS for Kancheepuram District, Tamilnadu, India.Model. Earth Syst. Environ, 6, 1105-1122.

Sashikkumar, M.; Selvam, S.; Kalyanasundaram, V.; Johnny, J. (2017). GIS based groundwater modeling study to assess the effect of artificial recharge: A case study from Kodaganar river basin, Dindigul district, Tamil Nadu. J. Geol. Soc. India, 89, 57-64

Selvam, S.; Magesh, N.; Chidambaram, S.; Rajamanickam, M.; Sashikkumar, M. (2015). A GIS based identification of groundwater recharge potential zones using RS and IF technique: A case study in Ottapidaram taluk, Tuticorin district, Tamil Nadu. Environ. Earth Sci, 73, 3785-3799

Selvarani, A.G.; Elangovan, K.; Kumar, C.(2016). Evaluation of groundwater potential zones using electrical resistivity and GIS in Noyyal River basin, Tamil Nadu. J. Geol. Soc. India, 87, 573-582.

Sewnet, A. (2016). Land use/cover change at Infraz watershed by using GIS and remote sensing techniques, northwestern Ethiopia. International Journal of River Basin Management, 14(2), 133-142.

Siebert, S., Burke, J., Faures, J. M., Frenken, K., Hoogeveen, J., Döll, P., \&Portmann, F. T. (2010).Groundwater use for irrigation-a global inventory. Hydrology and earth system sciences, 14(10), 1863-1880.

Tolche, A. D. (2020). Groundwater potential mapping using geospatial techniques: a case study of Dhungeta-Ramis subbasin, Ethiopia. Geology, Ecology, and Landscapes, 1-16.

Tripathi, R., Shyju, K., \&Jasim, H. R.,(2017). Evaluation of Ground Water Potential OfNallatangaalOdai Using Remote Sensing And Gis Techniques.

Wudad, A., \&Abdulahi, A. (2021). Expansion of ProsopisJuliflora and Land use Land Cover change in Korahey Zone of Somali Regional State, Eastern Ethiopia.

Yeh, H. F., Cheng, Y. S., Lin, H. I., \& Lee, C. H. (2016).Mapping groundwater recharge potential zone using a GIS approach in Hualian River, Taiwan.Sustainable Environment Research, 26(1), 33-43.

Yildiz, O., 2004. An investigation of the effect of drainage density on hydrologic response.Turk. J. Eng. Environ. Sci. 28 (2), 85-94 